\title{
INDONESIA-NORWAY COOPERATION TO REDUCE GREENHOUSE GAS EMISSIONS THROUGH REDD + SCHEMES (CASE STUDY: FORESTS OF CENTRAL KALIMANTAN)
}

\author{
Christin Sicilia Blandina Ansanay \\ International Relations, Universitas Kristen Indonesia, Jakarta, 13630, Indonesia
}

Itinansanay@gmail.com

\begin{abstract}
Environmental problems, in particular, climate change is of international concern as this issue is directly related to human life using natural resources such as forests, regardless of environmental carrying capacity and ecosystem sustainability. It will undoubtedly affect the economy because natural resources have economic and social functions that provide benefits and become the foundation for the sustainability of the lives of nations in the world, especially in reducing the impact of climate change. The purpose of this research is to know the cooperation between Indonesia dan Norway to reduce greenhouse gas emission (GHG) through Reducing Emissions from Deforestation and Forest Degradation (REDD+) scheme. The benefits of the research are theoretically useful for the development of the International Relations of science, especially concerning the cooperation of the environment. The theory used as the basis of the author in answering the question is the theory of constructivism. The method used in this study is descriptive qualitative. The results of this research indicate that the cooperation between Indonesia and Norway runs well through the preparation and transition phase, but not yet at the full implementation stage so that there has been no result of reduction of gas emissions a significant deforestation and degradation. However, this cooperation has a positive impact on improving forest governance for Indonesia and raising awareness government and communities to safeguard and conserve forests to reduce carbon emissions through the formation of policies in Indonesia.
\end{abstract}

Keywords: Indonesia, Norway, REDD+, Forests of Central Kalimantan, GRK

DOI: 10.33541/sp.v19i2.1650

Sociae Polites : Majalah IImiah Sosial Politik

Faculty of Social and Political Science, Universitas Kristen Indonesia

ISSN 1410-3745 print/ ISSN 2620-4975 online

Volume 19, Number 2 (July - December 2018)

Pages 145-162 


\section{Introduction}

\subsection{Background}

This research aims to explain the cooperation of Indonesia-Norway to reduce greenhouse gas (GHG) emissions in the forests of Central Kalimantan. Norway supports this REDD + scheme through the Letter of Intent (LoI) to reduce greenhouse gas emission from deforestation and degradation in the forests of Central Kalimantan.

This environmental issue is essential in the international world, considering that every economic, social, and political development indeed refers to the existing ecological problems. Environmental issues are now a threat and fundamental to a sustainable life. Trigger ecological issues caused by human population, growth, development, and technological developments, as well as environmental damage caused by humans through activities in the use of fossil fuels (80\%) As well as land-use activities $(20 \%)$ and degradation resulting in forests as the world's lungs, are decreasing (Jenie 2009, 35). When forests in the slash and excessive damage, the benefits of forests reduced, and the functioning of the forest as carbon dioxide absorber and oxygen providers be lost, thereby improving the emission of Green House $\mathrm{G}$ ases (GHG), which ultimately results in increasing Earth's surface temperature. This global warming phenomenon is called by global warming as a trigger for climate change (environment, 2016). Climate change is a crucial global issue, given its negative impact is increasingly not only on environmental sustainability but also on its implications for economics and social life.

Indonesia as one of the largest tropical forest owners in the world with forest cover area of 98,072.7 million hectares or about 52.2\% from its land area and known as the lungs of the world (Reddplus, 2015). By having such a vast forest, it estimated that every year Indonesia's forest area deforestation and degradation is caused by various populations. The demands of economic growth and weak forest management system in Indonesia such as land clearing, illegal logging, and forest burning, that caused the release of carbon in the forest to cause carbon pollution and increase the greenhouse effect in Indonesia (Nandika, 2005). It made Indonesia occupy $6^{\text {th }}$ place by producing 2.053 billion tons of CO 2 pollution from ten countries to contribute to the world's most abundant greenhouse gas (GHG) emissions. Due to deforestation and considerable degradation of forests occurring in Indonesia, especially in the region of Central Kalimantan. These conditions directly negatively impact economic and social aspects broadly, but also directly affect the indigenous and a local person whose survival depends on forests (Down to Earth, 2007).

The condition of Indonesia's forests whose quality has started to decline and the impact that has begun to make Indonesia play an active role in voicing the world countries and working. Towards addressing climate change environmental issues, especially for developed countries, to contribute more to the efforts to reduce greenhouse gas emissions (GHG) through REDD + schemes.

Besides, to minimize the breakdown of forests in Indonesia, through voluntary commitment to reduce greenhouse gas (GHG) emissions by $26 \%$ to $41 \%$ of emissions based on BAU scenario year 2020. The responsibilities are evidenced by the statement of President Susilo Bambang Yudhoyono (SBY) of the International Leader Summit in Pittsburg, USA, on 25 September 2009 and through registration officially as "Voluntary Emission Reduction" to the UNFCCC on January 31, 2010 (Forest Climate Center, 2009). President SBY also committed to realize a low-carbon economy as a transition to a green economy and change Indonesia's status as a carbon emissions release (NET- 
emitter) into an absorbent carbon (net sink sector). Because of Indonesia is a world lung that serves as a carbon storage/absorber (Hamami, 2012). Thus REDD + is regarded as a large-headed body to realize that commitment.

Norway, as an annex-1 or developed country, has committed to maintaining its greenhouse gas emissions of not more than $1 \%$ in the 2008-2012 period. Still, Norway's difficulties in doing so due to reducing greenhouse gas (GHG) emissions by $5.2 \%$ it means that the country is required to reduce emissions from 6 types of greenhouse gases (GHG), one of which is $\mathrm{CO} 2$. It states that Norway should reduce its industrial activities domestically, but this will harm Norway. Therefore, Norway has issued a $\mathrm{CO} 2$ tax policy in its country to reduce greenhouse gas (GHG) emissions. The issue of national policies and foreign policy that cares for the environment and to build sustainable principles and to cooperate with developing countries with tropical forests, one of which is Indonesia, this is have done to reduce greenhouse gas (GHG) emissions.

On 26 May 2010, Indonesia agreed to bilateral cooperation with Norway. The Government government saw an essential increase in environmental participation especially about the Reducing Greenhouse Gas Emissions from Deforestation and Forest Degradation Plus (REDD+) with the Royal Norwegian Government. The two countries 'agreement on REDD + had outlined in the Letter of Intent on Cooperation on REDD +. Based on the cooperation, the Norwegian Government provides incentives to the Indonesian Government in the form of grants to implement REDD + in Indonesia. The money allocated by the Norwegian Government amounted to US $\$ 1$ billion. The large allocation of funds depends on how effective the Indonesian Government achieves the target of greenhouse gas emission reduction (GHG). Cooperation conducted by Indonesia and Norway in the international environment in building the ability to plan reasonable solutions in the face of global environmental challenges facing countries in the form of climate change (Winarto, 2007).

The agreement mentioned that the Government should make a national strategy and provincial strategy for the province chosen as a pilot. Central Kalimantan became a focus of attention in the context of REDD + related to high carbon stocks on peatlands, but also central Kalimantan became the largest emission producer due to forest fires from the high reserves (Governor's Climate and Forests, 2011). With the primary Kalimantan forest used as a pilot, it has a significant influence on Indonesia and Norway to launch this program from REDD +.

\subsection{Research Question}

Based on the background of the above problem, to facilitate the author in conducting the discussion, the author formulates the following issues:

- How does Indonesia - Norway cooperate to reduce greenhouse gas emissions from the Central Kalimantan forest?

- What are the obstacles experienced in the process of implementing REDD + schemes as an effort to reduce Greenhouse Gas (GHG) emissions in the Central Kalimantan forest?

\subsection{Purposes and Objectives}

This research expected to be useful to enrich the knowledge about bilateral cooperation in addressing a problem. Especially the cooperation between Indonesia - 
Norway in the framework of reducing greenhouse gas emissions (GHG) through REDD + schemes in the forests of Central Kalimantan.

The results of this study will be useful as information additives and empirical studies for the study of international relations, which are interested in cooperation to tackle forest damage, especially the Central Kalimantan Forest, Indonesia. It oped that the Government and its stakeholders would be able to investigate Government's forestry program can be more targeted, precise, and as a matter of consideration and evaluation of research programs.

\section{Literature Review}

Previous research that authors refer to the literature review is a journal from Kadek Rina Febriana Sari (2015), titled "Australian effort in reducing carbon emissions through IAFCP cooperation in Kapuas Regency, Central Kalimantan. " In this research, there are similarities in analyzing the aims of reducing carbon/greenhouse gas emissions, but there are differences in the efforts to reduce carbon emissions from Australia and Indonesia through the cooperation of IAFCP in Kapuas Regency, Central Kalimantan. The results of the research from Kadek Rina Febriana Sari that bilateral cooperation conducted by Indonesia and Australia has very well done. However, the result has not been a significant form of gas emission reduction. Australia here emphasizes on increasing the capacity of systems that will later support the efforts to reduce gas emission from deforestation and forest degradation. Australia has made a positive impact on improved forest governance for Indonesia and in raising public awareness on government's role in reducing carbon emissions through the formation of various policies in Indonesia (Febriana Sari, 2015).

Meanwhile, Mahardy Azhar Aiman, in his research on the cooperation of Norway and Indonesia, reduced Greenhouse Gas Emission through REDD schemes, reviewing how the mechanism of cooperation between Indonesia and Norway through REDD + programs using Green Theory and the concept of Bilateral cooperation. The interaction made by Norway with other countries through foreign assistance in the form of REDD + is a joint responsibility that is realized by Norway to save the Earth, and this is evidence of the pro-environmental behavior of the country.

This bilateral partnership is in two directions, Norway as the national aid provider for Indonesia as a forest owner, and Indonesia as a forest owner must reduce greenhouse gas emission from deforestation and forest degradation. This cooperative relationship occurs because of a common belief that global warming is a common threat to all countries in the world, and these common threats deemed necessary to be addressed by common but differentiated responsibilities principles. That is, all countries have the same problem (global warming), but each state has its capability in handling it (Aiman, 2014).

In understanding more about the theory or concept used in this study, the author exposes the level of analysis used in explaining the problem that the authors are careful then the level of analysis used in this research is the nation-state analysis level. At this level of study, the country is the most instrumental actor in the international system, and the relative has the freedom to determine the policies to take. This level of analysis believes that the country is the dominant and most powerful actor in world life interactions. Norway has the freedom to determine its foreign policy, including in that it supports the REDD + program in the forests of Indonesia, especially the central Kalimantan forest.

Constructivism builds on the base of ideas, norms, cultures, and values as a 
primary that determines the identity, importance, and behavior of actors (states). Constructivism stated that the social environment determines the form of actors' identification. The character then determines the significance and the importance of learning the structure of conduct, action, or policy of the actors. According to Wendt, the construction process makes one can determine its significance.

Conflict or cooperation does not depend on the interests but depends on something that determines the importance of that something constructed, thus learning the interest (Wendt 1994, 389). So Wendt had the view that the country gained its identity and significance through the structure. General political conditions are made through the process, not already doomed as it is at a time, so the international structure not detached from the process that occurs through the actors ' practices. The country interacts with other countries and seeks to understand by looking at the behavior of the gestures shown by other countries. With the international structure, constructivism saw that the cooperation undertaken by the countries contained the values and norms that restrict the country to be fraudulent, as with international sanctions by the UN Security Council which made the state and other actors not to arbitrarily conduct a global level (Wendt 1992, 2).

The author tries to analyze using a constructivist perspective in understanding environmental issues. Norway and Indonesia view the situation as one of the tools for achieving its country's interests. Response resolution of environmental problems does not arise without a cause of consequence; there is a reason that constructs a state in taking action for the benefit of his country. The reason departs from various concepts of ideas and knowledge that formed from a social structure that describes the behavior of a country in each process of the policy formulation taken.

As with the meaning of Indonesia's Norwegian cooperation in carrying out the REDD+ Program in Indonesia, the desire does not arise. Still, there is a form of the social construction of the concept of understanding ideas and knowledge sharing of the benefits that Norway will get from its involvement in the global emission reduction efforts. The idea arises from social interaction in its participation in the International Convention of the UNFCCC environment that produces environmental norms and becomes the basis for Norway's reference in taking action to carry out its environment diplomacy in Indonesia through REDD + mechanisms. The policies issued by Norway and Indonesia constructed on matters that are always related to their national interests, included in Norwegian support of forests in Central Kalimantan, which is an effort to fulfill its national interestobjectives.

\section{Research Method}

This study conducted for six months, from March to August 2017. By using the method of data collection based on the review of the project Document (desk study), interview of the project's author and policy stakeholders, and the examination of the library. The study activities intended to obtain an overview and information related to the REDD + implementation process in the Central Kalimantan Forest, as well as this research using data analysis methods, where data collected in analyzing with qualitative descriptive analysis techniques. To describe the data in a manner that is orderly, burst, logical, not overlapping, and practical by the research topic to facilitate the understanding and interpretation of data. Analyses in this way aim to evaluate the development of REDD + pilot activities in the forests of Central Kalimantan. 


\section{Results and Discussions}

\subsection{Reducing Emissions from Deforestation and Forest Degradation Plus (REDD+)}

The UN Framework Convention on Climate Change (UNFCCC) is the result of an agreement from the Earth SUMMIT. The UNFCCC is an agreement that has finally been accepted universally as an international political commitment on climate change. The UNFCCC aims to stabilize greenhouse gas concentrations in the atmosphere, thus not disrupting the world's climatic conditions. The Convention entered into force from 21 March 1994, after ratified by 50 countries. Indonesia became one of the states that approved the UNFCCC by-law No. 6 of 1994 (Mailarchive, 2012). The highest decisionmaking Forum in the UNFCCC framework is the Conference of Parties (COP) held annually. The COP is responsible for reviewing the implementation of conventions and other legal instruments relating to the Convention.

Additionally, the COP is obliged to make the necessary decisions to improve the effectiveness of Convention implementation. The results of COP used as a mechanism for reducing greenhouse gas emissions, which is the Kyoto protocol in COP to 3 years in 1997. The primary purpose of the Kyoto protocol is to regulate UNFCCC participants to ensure that their greenhouse gas emissions do not exceed the agreed amount in reducing their emissions by at least 5\% under the 1990 emissions in the period of 2008 to 2012 (Deptan, 2012).

The implementation of the Kyoto protocol is felt less maximally by many parties and less effective in reducing greenhouse gas emissions (GHG). Therefore, the international world prepares a substitute agreement that expected to continue the ideals of the Kyoto protocol agreement called Reducing Emission from Deforestation and Forest Degradation (REDD). Reducing Emission from Deforestation and Forest Degradation (REDD) is an agreement designed as a substitute for the Kyoto protocol. The REDD scheme is an incentive-granting mechanism by an advanced industrialized country that should lower its greenhouse gas emissions to developing countries such as Indonesia as the owner of $50 \%$ of the world's tropical forests.

These incentives can encourage more sustainable forest management by providing a sustainable income stream. Emissions reductions are accounted for carbon credits. This incentive also urges developing countries to successfully reduce their carbon emissions by suppressing the level of deforestation activities and degradation of their forests. At the COP-13 in Bali, Indonesia, REDD agreed to agree on several important matters, such as the scientific, technical, and methodology aspects and information exchange. The original goal of REDD was to reduce greenhouse gases. REDD implemented with the principle of respecting the sovereignty of the State (freedom). A developed industrial nation that agrees in REDD, providing support for the capacity of building, technology transfers in the field of methodology and institutional, pilot/ demonstration activities.

REDD is two things integrated, first REDD as a goal and both REDD as a financing mechanism. As a goal, REDD expected to be a greenhouse gas emission (GHG) reduction scheme by reducing deforestation and forest degradation. As for financing mechanisms, REDD establishes financing or compensation procedures for deforestation and forest degradation efforts that expected to impact the decline in greenhouse gas emissions, especially CO2. REDD then broadened into REDD+, which is a forest management effort to prevent or decrease forest cover quantity and carbon stocks carried 
out through various activities to support sustainable national development (Pemhut No. 30/2009).

REDD+ includes not only reductions in greenhouse gas (GHG) emissions but also consists of the role of conservation, prolonged forest management, and increased carbon stocks. This scheme will help to lower the level of poverty and achieve economic growth and sustainable Development (Directorate General of PHKA 2013, 48). REDD + is one of the efforts to reduce global greenhouse gas emissions. The basic idea of reducing emission from deforestation and forest Degradation (REDD) is straightforward: countries that desire and can reduce emissions from forest deforestation should be compensated financially for doing so (Parker 2009, 14). The scope of REDD + activities, among others, is the reduction of emission (RED), reducing emission from deforestation and forest degradation (REDD), or an increase in carbon (REDD +).

The mechanism for reducing emission from deforestation and forest degradation $(\mathrm{REDD}+)$ can run when all stakeholders involved in obtaining benefits generated from REDD+ must accept by the appropriate stakeholders. The success of REDD + can meet the needs of local people and indigenous people. Success depends on the linkage between incentive and long-term development, rights to resources, and the participation of surrounding communities and distribution to all stakeholders of varying degrees.

\subsection{Indonesia-Norway Cooperation Relationship in REDD +}

As explained before, that study used constructivism theory to discuss IndonesiaNorway cooperative relations to reduce greenhouse gas emissions through REDD+ programs in Central Kalimantan forests. Bilateral cooperation Indonesia and Norway, because of the similarity identity as the country cares for the environment and awareness of the importance of the situation. The concern is reflected by the commitment of the two countries to reduce greenhouse gas (GHG) emissions, where Indonesia is committed to reducing emissions by 26 to $41 \%$, as President Susilo Bambang Yudhoyono said at International Leader Summit in Pittsburg, United States. Indonesia's commitment to reducing greenhouse gas emissions is an excellent move to realize a low-carbon economy or green economy and change Indonesia's status as a clean emission absorber because Indonesia is the world's lungs. Norway's concern for the environment reflected by the foreign policy adopted by Norway, not regardless of environmental issues and Norway, is committed through the emission reduction action Plan of $30 \%$ in 2020 . Here is what constitutes the importance and affects the actions of both countries to cooperate and to realize the commitment of the two countries by implementing REDD + schemes in Indonesia, especially the central Kalimantan forest through the phase outlined in the Letter of Intent agreement.

Diplomatic relations between the Republic of Indonesia and Norway had begun since 25 January 1950, where Norway officially opened a Jakarta embassy office on 27 April 1971 and the opening of the Indonesian representative office in Oslo in 1981. Indonesia and Norway Bilateral relations have been established for approximately 60 years. In recent years, the relationship between the two States experienced a significant increase. Other bilateral relations, RI-Norway shown the visit of the President of Indonesia to Norway on 12-14 September 2006 as well as a visit of the Norwegian Prime Minister to the Philippines on 28-30 March 2007. On 26-28 May, president of INDONESIA held a working visit to Norway to become Co-Chair together with Norwegian PM Jens Stoltenberg at the Oslo Climate and Forest Conference 2010. 
Furthermore, the Norwegian Foreign Minister visited Indonesia on 6-8 November 2010, with the Minister of Foreign Affairs has signed the Joint Declaration on Cooperation towards a Dynamic Partnership in the 21st Century which focuses the cooperation of both countries in the field of human rights, environment, Forestry, energy, marine, and Fisheries (Norway, 2010). The declaration pressed on the importance of various ongoing cooperation between the two countries, particularly related to the demands of globalization and future challenges in international forums.

At the G-20 meeting in Pittsburgh, the United States in 2009, President Susilo Bambang Yudhoyono raised a commitment to reduce Indonesia's emissions by $26 \%$ in 2020 and $41 \%$ if they received international support (Aprilia, 2016). President SBY demonstrated the willingness and leadership potential to reduce the impact of climate change. Other countries immediately welcome these absolute target assignments. Norway became the leading country to express its appreciation and said it wanted to help the Indonesian Government's efforts to achieve that commitment. Norway argues that forests have a very significant role in preventing climate change and Indonesia as the owner of the third-largest tropical forest in the world.

There is various biodiversity, as the lungs of the world that serves as a strategic provider of the needs of the world's clean air and tropical forests play an essential role in the global climate. As an industrial country belonging to the Annex 1 State of the Kyoto Protocol, Norway should lower its country's carbon emissions, mainly because of its high levels of fossil energy, industrialization, and transportation. Related to the inability of Norway to reduce carbon emissions, then one of the roads is giving grant incentives to the developing country's forest owners. This grant is in line with the COP agreement. Indonesia is one of the world's most diverse biodiversity with tropical forests that play an essential role in the global climate. The purpose of this environmental cooperation is to produce a work plan for environmental management and natural resources using an ecosystem approach.

Indonesia and Norway recognize the importance of the environment and the impact of local and global people's lives so that both countries agree to cooperate and engage in partnerships as an effort to support the reduction of emission from deforestation and degradation of forests and peatlands. Cooperation on 26 May 2010 and outline in "Letter of Intent the Government of Republic of Indonesia and Kingdom of Norway on Cooperation Greenhouse Gas Emission Reducing from Deforestation and Degradation," which contains funding of up to USD 1 Billion for Indonesia on the implementation of REDD+ using the principle of performance-based payment. The Letter of Intent will be valid until the end of the year 2016. It will renew automatically unless either party is notified of notification or notification to terminate through a diplomatic route.

The cooperation between Indonesia and Norway will be conducted in three phases. The first phase, i.e., the preparation phase or readiness, are the main preparatory steps for implementing the REDD + Indonesia strategy by finalizing Indonesia's climate and forest strategies and implementing institutional policies \& reforms. The second phase, where Indonesia's efforts and Norwegian support will focus on developing national capacity, development, and implementation of the system, change, and enforcement as well as full-scale REDD + trial activities at the provincial level. The third phase is the implementation of emission reduction mechanisms based on the contributions verified.

Through the cooperation, Indonesian to the Government, Susilo Bambang Yudhoyono, expects the success of this cooperation. This step assessed as a real step taken by Indonesia in implementation following up the commitments that have made and through the Indonesian letter of intent for Norway in the cooperation of REDD. 
Expected to be models and examples for each country that want to reduce its greenhouse gas emissions, especially those countries that belong to the state Annex 1 in the Kyoto protocol (Iqbal Sani 2016, 8).

\subsection{REDD+ Programs in Indonesia}

Indonesia's commitment to reduce emissions by $26 \%$ without foreign aid and or $41 \%$ if there is foreign assistance in 2020 becomes a separate betting when the determination must integrate into Indonesia's development policy. Responding to Indonesia's commitment, overseas support began arriving. Not only in debt form but also in the type of grants with tremendous amounts. MoU between Indonesia and Norway in May 2010 in the way of LOI is one form of assistance received by Indonesia related to Indonesia's intention to reduce emissions by $41 \%$, compared to emission reduction through the REDD + .

The Indonesian Government is tied to a cooperation agreement with donor countries to achieve specific targets in reducing emissions through the REDD+ and the prevention of its forest degradation. The Government established the Indonesia Forest-Climate Alliance (IFCA), the National Council on Climate Change (NCCC), and the REDD + Satgas as a unique body that handles the affairs of REDD + Indonesia programmatic program. Before the REDD + Task Force (REDD + Force) formed, the implementation of LoI was bestowed on three institutions: Bappenas, Ministry of Forestry, and UKP4, under the coordination of Coordinating Minister for Economic Affairs. Bappenas is responsible for drafting the REDD + National Strategy, the Ministry of Forestry is responsible for selecting the pilot province, and UKP4 is accountable for developing REDD + institutions, funding mechanisms, and MRV systems. The REDD + Task Force then formed under Presidential Decree No. 19/2010. The REDD + Task Force is an ad-hoc institution tasked to institutionalized coordination between various institutions involved in REDD+ (Indrarto, 2013). The Taskforce formed as an answer to the LoI between the Indonesian and Norwegian governments.

The implementation of REDD refers to two things, namely; the process of establishing a payment mechanism to a developing country that has reduced its emissions from deforestation \& forest degradation. Activities that refer to preparatory activities for forest-owner countries to engage in REDD mechanisms, which will at least undertake testing and development of methodologies, sustainable forest management technologies, and institutions that seek to reduce carbon emissions. In Indonesia, the second reference knows as Demonstration Activities (DA), (Muhajir 2010, 11), or in the REDD + Indonesia scheme, DA entered into the pilot/transitional stage.

\subsection{REDD+ Indonesia Preparation Phase}

The preparation phase of REDD+ Indonesia began in 2010. Some progress had achieved in the field of anti-corruption promotion, raising awareness, plans, and the framework of ownership \& national institutions. Implementation of a moratorium on two years of new concession permits for the conversion of natural and peatland forests, as well as credible degraded land base data, not yet achieved (Greenpeace 2012, 3). To follow up on the results of the IFCA Research in 2007, which then became the basic framework of the national strategy of REDD + Indonesia, then the REDDI strategy for the preparation phase of REDD + Indonesia. This strategy intends to guide policy intervention required in 
the effort to handle the root of REDD+, and infrastructure to prepare in the implementation of REDD +. This strategy also integrates all REDD + related actions, including activities that are in the Fund from overseas sources.

Readiness strategy covers aspects of methodologies and policy aspects, as well as support activities such as capacity building and stakeholder communication. (Marispatin $2010,11)$ The plan of Readiness REDD + Indonesia is not only beneficial in supporting Indonesia's readiness in preparing for REDD + implementation under the UNFCCC framework, but also part of Indonesia's strategy and efforts to realize Sustainable Forest Development. In this phase, Indonesia also establishes funding institutions and instruments to facilitate the organization of REDD+ programs permanently through financing services and funding distribution covering all sources, both public and private, from domestic and overseas and reaching the acceptance of REDD + benefits to the level of community in and around the forest.

Indonesia then established REDD+ pilot provinces to implement early-stage trials and monitor the progress of national REDD+ readiness. In this activity, the development of demonstration activities (Demonstration Activity/DA) for REDD+ in the form in various provinces in Indonesia to provide learning during the preparatory phase and to build commitment and synergy between the parties. Demonstration activities for the pilot/transition REDD+ Indonesia phase continue to implement. Some of the provinces that chose as the place for DA held include Jambi, South Sumatera, Aceh, Riau, West Kalimantan, East Kalimantan, Central Kalimantan, Papua, and West Papua (Indrarto 2013, 58). In December 2010, central Kalimantan chose as the first pilot province in Indonesia for cooperation between Norway and Indonesia.

\section{- Central Kalimantan Pilot Province}

At the plenary Cabinet session on 23 December, President decided to Central Kalimantan (Kalteng) as a pilot province. Therefore, in the first phase, President Susilo Bambang Yudhoyono chose Central Kalimantan province as a pilot province implementation of the first REDD + trial. The agreement mentioned that the Indonesian Government should create a national strategy and provincial strategy for the province chosen as the pilot (Antarnews, 2010). The election of central Kalimantan as a province of implementing REDD+ implementation in Indonesia, including for the following reasons:

a. Central Kalimantan province is the $3^{\text {rd }}$ largest province in Indonesia after Papua and East Kalimantan with an area reaching 1.5 times the island of Java, consisting of 13 regencies and 1 Kanto of the city. Related to the utilization of land and space and Earthsea oEarthh and earth, where the province of Central Kalimantan has extensive forest area, even in terms of productivity is the widest in Indonesia, so the biodiversity is the most complete in Indonesia.

b. Central Kalimantan since 1993 in cooperation with the International party researching tropical peat swamp forest by establishing the peat Forest Natural Laboratory (LAHG) in DAS Sabangau; carried out several times the international Peat Workshop and Symposium (i.e., 4-8 September 1995 and 20-24 September 2005) in Palangka Raya.

c. Natural forest areas as carbon dioxide absorbent and oxygen supply, as well as peatland as perverts Karbon, are still widely available. 
Before the Central Kalimantan province designated as a pilot province of REDD + since 2006, the regional government program of central Kalimantan province has aligned with REDD + concepts and issues. After the administration of the Central Kalimantan as a pilot province of the LoI cooperation, the Government of Central Kalimantan inaugurated various REDD+ activities, including the MoU between the Chairman of the Task Force of REDD+ and governor of Central Kalimantan in 2011. Which then became the cornerstone of cooperation REDD+ activities in this province (Forest Watch Indonesia 2014, 6). Regarding LoI Indonesia-Norway, the government of central Kalimantan Province took the initiative to develop REDD + regional strategy (Strada REDD +).

In drafting the Strada REDD+, th e government of central Kalimantan included seven agendas that built and developed the REDD+ Support Office and involved multilevels and multi-sectors stakeholders. Set base map and necessary information to start data integration and monitor its progress; of low-carbon development, including quantifying environmental and socio-economic impacts. To implement delays in the issuance of new permits and improvements in forest and peatland governance, as part of a nationwide moratorium. Build the local capacities of central Kalimantan and other REDD + provinces, and build awareness and knowledge of REDD + and a halt; Identify and implement quickwins initiatives to demonstrate and provide real impact; and implementation of forests for indigenous peoples (WWF 2015).

Based on the plan above, the national Government has the purpose and strategy of the Action Plan program in the framework of reducing carbon emissions in line with economic growth for the welfare of the central Kalimantan community. Although central Kalimantan is known as one of the provinces that has a large forest area, there are still many problems that occur in this province. Environmental issues are not only happening because of natural factors but can also cause by human factors. If allowed to continue to protracted, this will undoubtedly cause other problems in the province of Central Kalimantan. However, to date, since established as a pilot province, from several phases of preparation, central Kalimantan has several steps ahead of other regions because some initiatives implementing the program that carries REDD+ have been implemented and running until now (Central Kalimantan Governor 2011).

\section{B. REDD+ Transition Phase}

The Government has completed the targets in the first phase of preparation. The second phase began in January 2011 until the end of the year 2013. In this phase of transformation, Indonesia's efforts and Norwegian support will focus on developing national capacity, development, policy implementation, and reform and enforcement as well as one or more of the full-scale REDD + trial activities at the provincial level. So the target of this phase is to make Indonesia ready to implement the third phase of the emission reduction phase based on verified contributions.

In this phase, Indonesia is forming a system MRV system (Measurement, Reporting, and Verification) systems, report, and verification of greenhouse gas emission reductions $(\mathrm{GHG})$ is an essential process in REDD + activities. Know the performance of the implementation of greenhouse gas (GHG) emissions reduction activities through REDD +; the results of MRV will be used as the basis for the payment of emissions reduction performance and utilization to identify REDD+ from social, economic, or political. Indonesia is one of the world's most significant contributors to greenhouse gases (GHG) emissions, a portion of emissions derived from forest and peatland clearing. On 20 
May 2011, the Government issued Presidential Instruction No. 10/2011 on forest Moratorium policy on issuance of new permits and improvement of the governance of primary forest and opening Peatland. It is one of the agreements signed by the Indonesian letter of intent with Norway on 26 May 2010 as part of the REDD + deals worth 1 billion USD (Down to Earth, 2011)?

\section{Contribution Phase/ Full Implementation}

The objectives and focus of the partnership stated in the Letter of Intent, especially REDD+ policies, collaborate and provide support for the development and implementation of REDD+ Indonesia strategies. The mutual desire of both sides was to start the third phase in 2014, based on the emission reductions of 2013 . In this phase, emission reduction mechanisms based on verified contributions will be implemented, including:

a Indonesia receives annual contributions to independently verified national emission reductions according to the UNFCCC reference rate or reference level determined by Indonesia and its partners based on Indonesia's emission reduction pledge and UNFCCC methodology guidelines, following decisions relating to the Conference of the Parties (COP), if the UNFCCC reference rate for Indonesia has not established.

b. Norway (possibly other partners who join this partnership) distributes the financial contributions to financial instruments as outlined at the First phase (Letter of Intent) of greenhouse gas reduction cooperation (GHG).

The full implementation of REDD+ schemes is complicated to implement. It is a challenge for Indonesia to implement REDD+ in full to meet concrete targets. There are several problems that Indonesia has to face in implementing REDD+ to include various groups with different interests, carbon counter technology for carbon calculations can do transparently. Emission reduction verification can be done quickly, incentive payments, accountability is made to ensure that carbon payments can realize against sustainable forest protection and funding to help Indonesia implement REDD + in full in the third phase.

Indonesia has entered its full implementation phase. The Government of Indonesia is committed to lowering its greenhouse gas (GHG) emissions by $26 \%$ while maintaining economic growth by $7 \%$. This emission reduction effort can be increased up to $41 \%$ with international aid, to realize the commitment of the Government in cooperation with the government government to run this agenda jointly. There is no certainty about the implementation phase of REDD + Indonesia. In addition to the D A / Demonstration Activities projects, difficulty in setting the REDD + base, and funding for REDD + implementation. Based on the payment of REDD + performance until now has not realized because problems are facing relate to REDD + projects that have to implement and measure emissions reductions so that many conclusions based solely on speculation (Wunder 2010, 76). So, the third phase of REDD + Indonesia implementation has not yet had a bright point related to the achievement that has occurred.

Greenpeace itself illustrates that the development of REDD+ in Indonesia is slow and still raises the question of whether a set period can implement before payment based on the performance of greenhouse gas emissions reduction from 2014. While some progress has been achieved in the field of promotion of anti-corruption, raising 
awareness, plans and frameworks of national ownership and institutions, implementation of the moratorium two years of new concession permits for the conversion of natural and peatland forests, as well as a credible database of degraded land, has not been reached. (Greenpeace 2012,3)

\section{Barriers in Implementing REDD + Schemes in Indonesia}

a One of the obstacles faced comes from in the REDD + mechanism itself, which is how to measure the carbon accurately, how to ensure the funds to the forest community with transparency and efficiency, who will be responsible if the forest is still damaged, and the source of funding. More than 30 models of how REDD+ should implement have proposed by various countries and non-governmental organizations.

b. The phenomenon of forest fires causes damage to forest areas. In this case, the Minister of Environment and Forestry RI, Siti Nurbaya, stated that 99\% of forest fires caused by human behavior (based on empirical data and 17 years of research studies) (Republika, 2015). Through the recall of about $60-80 \%$ of Indonesian emissions, donors derived from activities in the forestry and peatland sectors originating from forest fires Deforestation and land-use. When it said that the forest fires that destroyed forests happen in Indonesia due to human behavior or actors. Then, in this case, can be seen from the actions of companies or industries such as oil palm companies, pulp, and paper companies and coal mines dominated by several conglomerates (foreign investors) are the same by controlling the logging industry and timber Management (FWI, 2014). The company destroys forests by burning and cutting forests to open new land or expansion of plantations, agriculture, and mines in Indonesian forests; it transforms the use of land functions from the primary forest and peatland to farms, agriculture, and tunnels. Therefore, forest burden increased because of changing forest function by damaging the wood for the opening or expansion of plantation land.

c. REDD + Independent agency foundries National Council on Climate Change (NCCC) and REDD + Management Agency (MA), both independent agencies in government as independent agency or agency that controls the course of implementing REDD + mechanisms at the global and national level directly under the President. The institution in the form of strengthening Indonesia's position to encourage developed countries is more responsible for climate change control (Witoelar 2009, 23-24). During the reign of President Joko Widodo precisely 21 January 2015, issue the presidential Regulation (Perpres RI) No. 16 of 2015 about the Ministry of Environment and Forestry, NCCC and MA REDD + functions are dispersed into the Ministry of Environment and Forestry and will integrate with the Directorate General of Climate Change control of the Ministry of Environment and Forestry. The shops are mandated by the President of INDONESIA to realize a lean state institution, budget savings, and avoid overlapping institutions that have the same duties and functions, so it intended to improve the efficiency and effectiveness of government affairs. The essence of this NCCC and MA REDD + is that in the Ministry of Environment and Forestry (MEF) is to cut off or cut out the existing bureaucracy and to facilitate the organization in one roof. However, when the independent institutions that control the course of the REDD+ scheme in Indonesia must dissolve, then a little more will have an impact on the target and the work to 
achieve by Indonesia. Through the commitment of the Indonesian Government to reduce the world's emission rate and also a promise to an agreement with the government.

d. Indigenous peoples, as Indonesians, they reside in the vicinity of forests. For them, forests are a source of life and producers where indigenous peoples can manage forests according to their life needs such as gardening, hunting, traditional medicines, raising livestock, and even as a place of ritual. Indigenous peoples use a pattern of land ownership of a community that refers to the public and its use based on deliberation.

The obstacles from implementing REDD + schemes in Indonesia have a significant impact. Therefore, in implementing REDD + mechanisms in Indonesia require a lengthy process and should be prepared ripened if you want to produce something maximal. Thus, the implementation of REDD + in Indonesia not always go smoothly; many challenges and barriers that are experienced by Indonesia as an important point for each trip of REDD + activities in Indonesia. It is necessary to have a good relationship and great support for the sustainability of the forest and the community, a key to the management of forest resources for the maximum benefit of the city. This REDD + scheme as one of the Government's national programs can control and facilitate the preparation and implementation of indigenous peoples ' activities to engage in a federal program of sustainable development, fair and following the principle of sustainable development with national equality.

\section{Conclusion and Recommendation}

\subsection{Conclusion}

Based on the research that has done and what has shown in the previous chapter. Researchers can then take the conclusion of Indonesia - Norway's cooperation to reduce Greenhouse Gas (GHG) emissions through the Reducing Emissions from Deforestation and Forest Degradation Plus (REDD +) scheme in the central Kalimantan Forest. Environmental issues are an essential and crucial issue because the environment has an important role that is the development of capital and the support of human life. Thus, the problem that is made by the environment will impact and threaten human life. And makes the environment an international issue that covers climate change issues, global warming, and more.

The complicated problems and challenges faced to solve the issues of the environment by the countries of the world, both by developed countries and developing countries, are quite challenging and have to pass a long process. Therefore, developed and developing countries think to cooperate to address environmental issues because this issue is a global problem that needs to overcome jointly. All countries that are in a worldwide system order that has relations between governments, businesses, communities, and nature will choose to establish a deal or partner with world countries, both bilateral, regional, and multilateral.

Indonesia and the Kingdom of Norway are aware of the need to make efforts to reduce greenhouse gas (GHG) emissions both at national and global levels. Therefore, the two countries agreed to cooperate in a partnership as an effort to reduce GHG emissions by maintaining and managing forest areas sustainably. And effort between the Government of Indonesia and Norway is contained in three phases in the "Letter of Intent" on the 
reduction of greenhouse gas emission (GHG) emissions through REDD+ schemes. Includes providing funding for up to 1 billion USD to Indonesia to help the Indonesian Government to prepare and implement REDD + schemes in Indonesia.

In implementing the REDD + program following the level agreed in the Letter of Intent, the Government must achieve targeted emission reduction targets. When Indonesia has succeeded in lowering greenhouse gas (GHG) emission from deforestation and degradation of forests and peatlands, Indonesia will receive incentive funds as a result of the contribution in preserving Indonesia's forests.

So to achieve these targets, the Indonesian Government incorporated REDD + schemes as a national policy on sustainable environmental and forest management to achieve low-carbon economic growth. However, in the implementation of REDD+ in Indonesia, some barriers inhibit REDD + programs in Indonesia. As such, forest damage resulting from forest fires and land use by humans is one of the leading causes of climate change, the melting of independent institutions, namely NCCC and MA REDD + into the Ministry of Environment and Forestry. Also, indigenous or local people residing around the forest area is a significant obstacle to the course of REDD +. By the absence of barriers not only inhibits the implementation of REDD + schemes but also inhibits the granting of incentives funds from the results of Indonesia's contribution in safeguarding its forests.

In the end, the cooperation Indonesia and Norway can make an excellent contribution to reducing greenhouse gas emissions (GHG) through the implementation of REDD + schemes in the forests of Central Kalimantan. That has been several steps ahead than other provinces because some initiatives implementing the program that carries REDD+ has been implemented and running until now. The impact of this REDD + program is the most extensive opportunity for the community to deliver its aspirations, the incentives give in local communities, people aware of the issue of climate change, the interaction and support of various parties, the community.

Knows the flow of incentive funds transparently, the public can do sustainable development without damaging the environment. Implementation has been running well through the preparation and transition stages. Still, it has not yet reached the full implementation stage, so there has been no significant reduction in greenhouse gas emission from deforestation and degradation. However, this partnership has made a positive impact on improving forest governance for Indonesia and raising awareness of Governments and communities to safeguard and preserve forests as an effort to reduce carbon emissions through policy formation in Indonesia. The reduction of greenhouse gas (GHG) emissions through REDD + schemes can be a solution to climate change and to implement sustainable forests and achieve equitable and sustainable development of the people. Therefore, Governments need to establish partnerships between Governments and involve the role of community in implementing REDD + to deliver reasonable, sustainable development goals.

\subsection{Recommendation}

1. The author suggests that the cooperation made by both countries is further improved, continued in the later phases, considering that this cooperation is a big step for Indonesia to prove its commitment to the international world related to environmental awareness, moreover, plus the REDD + program funded by developed countries such as Norway, this is undoubtedly an excellent opportunity for Indonesia to maximize its forest potential and in addition to developing 
Indonesia's economy

2. There needs to a strengthening legal framework and transparent policy to provide clear ownership of natural resources in governance. The moratorium should increase by incorporating all forest areas and all lands categorized as high carbonvalue areas, land cover maps \& credible use, and legal force to identify degraded land. The economic development zones, conservation areas, indigenous peoples' land rights, forest protection and biodiversity, agricultural and mining concessions in a consistent manner then REDD + in Indonesia will be able to achieve progress rapidly.

3. The need for expected updates, with further support and effort to ensure that REDD + generates changes, as stated in the LoI Indonesia - Norway, can continue without any obstacles. And can have a positive impact on both countries so that the interests of the two countries to reduce greenhouse gas emissions (GHG) achieved.

4. The socialization of REDD + needs to be improved, as there are still village people who do not know the programs implemented by REDD + from the village elites and government. With the introduction of REDD schemes to the community, especially those who live around the forest in Central Kalimantan and other provinces so that they can participate in the efforts to preserve the wood. 


\section{BIBLIOGRAPHY}

\section{Book}

Indrarto, Giorgio Budi. 2013. Konteks REDD+ di Indonesia. Pemicu, Pelaku, dan Lembaganya. Bogor: CIFOR.

Marispatin, Nur. 2010. Strategi REDD - Indonesia Fase Readiness 2009-2012 dan Progres Implementasinya. Jakarta : Departemen Kehutanan

Muhajir, Mumu. 2010. Tanggapan Kebijakan Perubahan Iklim Di Indonesia: Mekanisme Reducing Emissions From Deforestation And Forest Degradation (REDD) Sebagai Kasus. Indonesia: Episteme. Foundation.

Parker, Charlie. 2009. The Little REDD+ Book. Oxford: Global Canopy

Wendt, Alexander. 1994. Social Theory of International Politics, American Political Science.

Review vol. 88 no. 2.

Wunder, Sven. 2010. Melangkah Maju dengan REDD. Isu, Pilihan, dan Implikasi. Bogor: CIFOR.

\section{Journal}

Jenie, Rezlan Ishar. 2009. -Perubahan Iklim: Jalan Panjang dari Bali Menuju Kopenhagenl. Jurnal Diplomasi: Merawat Bumi dengan Diplomasi, Vol. 1, No. 3.

\section{Report}

Dokumen Kalimantan Tengah. 2011. Booklet Draft Governor's Climate And Forests Take Force.

Forest Climate Center. 2009. Intervention by H.E DR. Susilo Bambang Yudhoyono, President

of The Republic of Indonesia on Climate Change at the G-20 Leaders Summit.

Forest Watch Indonesia. 2014. Potret Pelaksanaan Tata Kelola Hutan: Studi Kasus Kabupaten Barito Selatan Provinsi Kalimantan Tengah . Bogor: Forest Watch Indonesia.

FWI. 2014. Dibalik Kerusakan Hutan Indonesia. Bogor: Forest Watch Indonesia. Greenpeace. 2012. Surat Niat Indonesia-Norwegia untuk Menurunkan Emisi Gas Rumah

Kaca dari Deforestasi dan Degradasi Hutan : Kajian Kemajuan dari Greenpeace.

Gubernur Kalimantan Tengah. 2011. Proposal Untuk Provinsi Pilot Reducing Emissions from Deforestation and Forest Degradation (REDD+). Palangka Raya: Pemerintah Daerah Provinsi Kalimantan Tengah.

Jagau, Yusurum. 2013. Laporan Kemajuan Pelaksanaan REDD+ di Kalimantan Tengah.

Palangka Raya: Komda REDD+ Kalimantan Tengah. 


\section{Website}

AntarNews. 2010. -Presiden Pilih Kalteng Provinsi Percontohan REDD. Diakses pada 04 April 2017. http://www.antaranews.com/berita/239939/presiden-pilihkalteng- provinsi-percontohan-redd.

Down to Earth Indonesia. 2007. -Perubahan Iklim Pencegahan Deforestasi dan Indonesia.http://ww w.d owntoe arth indone sia .org/id/story/pe ruba ha $\mathrm{n}$-iklim pencegahandeforestasi-dan-indonesia.

Down to Earth. 2011. |REDD di Indonesial. http://www.downtoearthindonesia.org/id/story/redd-di-indonesia-berita-terkini.

Departemen Pertanian.I UNFCCC\| http///www.deptan.go.id/kln/pdf/unfccc.pdf.

Norwegia. 2010. -Pengantar Dari Duta Besall

http://www.norwegia.or.id/Embassy/Pengantar_dari_Duta_Besar/.

Norwegia. 2010. -Bentuk-Bentuk Kerjasama RI-Norwegia. http://www.norwegia.or.id/Embasy/bentukbentuk-kerjasama-norwegia- indonesia/.

Republika. 2015. -99 Persen Kebakaran Hutan Karena Ulah Manusial. http://www.republika.co.id/berita/nasional/umum/15/01/08/nhuud5-99-persen- kebakaranhutankarena-ulah-manusia.

WWF. 2015. "Inisiatif Para pihak Dalam Rangka Wujudkan Ekonomi Hijau di Kalimantan Timurl. http://www.wwf.or.id/?35403/Inisiatif- Parapihak-Dalam-RangkaWujudkanEkonomi-Hijau-di-Kalimantan-Timur. 